\title{
Sentencing Postponed in the Penal Code in 1392
}

\author{
Mohammad Lashgari ${ }^{1} \&$ Zahra Abedi Nezhad Mehrabadi ${ }^{1}$ \\ ${ }^{1}$ University of International Training Center of Khorramshahr (Persian Gulf), Iran \\ Correspondence: Mohammad Lashgari, University of International Training Center of Khorramshahr (Persian \\ Gulf), Iran.
}

Received: April 12, 2016 Accepted: June 15, 2016 Online Published: October 30, 2016

doi:10.5539/jpl.v9n9p1

URL: http://dx.doi.org/10.5539/jpl.v9n9p1

\begin{abstract}
Sentencing postponed is one of the new installations of IPC (The Islamic Penal Code) that its Basics of criminology have not been studied yet. Hence, human approach to punishment and reduce resort to punishments can cause decrease in crime and commits compatibility. Postponing the Sentence towards criminals in order to decriminalize and not resort to punishment is one of the institutions that can achieve to the Goals considered by Criminal Matters policymakers In order to reduce recidivism. Therefore Iranian legislator well as in order achieving the objectives of long-standing human means reducing crime rates, is trying to impose new facility with Reform-driven approach. Postponement of the sentence is one of the Facilities that in The Penal Code adopted 1392attracted the attention of Legislator postponing institution by delaying the sentence gives the opportunity to the offender to return to society, And once again resume a healthy social life. Postponing sentence is leniency that only is includes limited offenses with prescribed punishment. Crimes that because of their non-violent and light of them and less dangerous of their commits Faster and easier leads to reduce recidivism and offender rehabilitation. this study holds that by Documents library method (analytical descriptive), paid to the new installations Islamic Penal Code related to the postponed sentence of offenders and crimes and offenses that would be subject to such a ruling. It should be noted that the statistical community of this study is all books, articles, laws and reputable sites that researchers in the current study uses them.
\end{abstract}

Keywords: The Islamic Penal Code, postponed sentence, the principle of individualizing the penalty, suspended

\section{Introduction}

A person, who commits the crime, disrupted the existing order in society and manifests its Hostility again community norms. In addition that he provide Causing violation of people's rights in society, he/she harms to society. Such a person through committing a criminal act is exposed to the punishment and Security measures. In fact, punishment, Security and Corrective Measures is primary effect of criminal conviction due to act contrary to law and order (mass) of the members of the community. But the consequences and effects of this anti-social and criminal act are not limited to penalties and corrective and Training measures; because criminal conviction has other effects for offender. Among which we can mention the following: Existence repetition of the offense and regulations in case of committing a new offense, Prevents the suspension of punishment and Delay sentencing for committing some crime and exclusions of civil rights. In fact, a person with committing the crime In addition to being subjected to punishments and corrective measures leaving a certain attitude from itself in the society. Such, after that the look of the society toward him has been changed and society does not consider him like other people. Thus, in case of re-offending by him, such action implies the existence of hazardous conditions and lack of discipline is wished and amplifies his punishment. The other is that committing certain crimes and a history of committing to it is leading to person inability to use of the provisions suspension penalty and postponed sentencing. Also existence history of criminal conviction leads Lack of enjoyment of social rights for a period of time. the basis of the above abuses actions is that Jurisdictions require that for period of time dangerous criminals are deprived of social rights so that society protected from action of such person And also being agent for people to prevent crime. But it must be said that the imposition of the exclusions and prohibitions should not be permanent. Upon attaining person to the reforms And after a period of sanctions that Depending on the type of crime This exclusions and prohibitions should be removed under conditions. So we're here to investigate this matter that criminal person how long after enduring penalties suffered The other consequences and effect of its crime, And over what time after the person returns to the state before the committing the crime And since then he, like other members of society (Lack of offending) will be treated. 
Hence sentencing delayed, Is one of the most important effects decriminalize, that Without any legal background, the first time in the Islamic Penal Code in 1392, is predicted. The implementation of this mechanism is possible only in the realm of prison sentences, gives the ability and authority to judge that after obtaining convictions - In certain circumstances-Criminal convictions sentencing in grade six to eight Crimes sentenced postpone for six month to two years.

\section{Chapter One}

\subsection{Definition of Crime}

Crime literally means the sin (Abazari Fumeshi, Mansour, 78-24). And the term, despite the many definitions of crime there isn't still a good definition of the crime that being acceptable to all and being worth the time and place. And the reason for this is that the phenomenon of crime in terms of scientists and researchers, has different foundations and various forms, In other words, what is considered crime in the view of one scientist, in the view of other scientist not only may not take as a crime, It may even be considered as good practice. (Ebne Ghadameh, Abi Mohammad Abdolah ben Ahmad. 1367.85).

\subsection{Suspension Literal and Technical Meaning}

Fulfilment of orders and judgments issued by qualified courts is as one of the most important stages of the proceedings, In fact, at thisis stage of the proceedings that Judgment practically achieves their rights. But in some cases the legislator allows that a final judgment rendered by a court for reasons delay or postpones or stop.

Postponement in term of word means stop and delaying (Doglas, Gilian. 1383).

In Elsewhere in relation to the meaning, of delay or postponement has come: Put something after instead and delaying (Zaker Hossein, Mohammad Hadi, 421388)

This is called in Latin the phrase "Adjournment" within the meaning of the following is used:

An act of period of adjourning, being adjourned

Action related to postpone-being Adjourned to other time

In France, the "Adjournment" means follows:

Action Bacourner Quelque Chose

Action to postpone something (adjourn to the other meeting).

In term of idiomatic postponement meaning, after the court session, When the court examined the available evidence, If a defendant whose him guilt has been proved to court has a condition exists in law, the curt delay his Condemnation Verdict Issuance.

Thus, for some suspending and delaying to do something to the future its literal meaning is used. Although in Islamic Penal Code does not provide a definition of this institution, It must be said deferred sentence means the Authority OF Competent court to postpone the sentencing After criminalize offenders (Grant, Willaim, 1988).

In fact, the judge according the conditions and situation of Guilty, and his personal social and family characteristics Postpones verdict, and this decision caused Improvement reform and socialization of the Guilty.

In this way postponement of the sentencing can be defined as follows:

"No verdict after the incrimination of the perpetrator According to nature of the crime and his personal characteristics"

\subsection{Pursuit Suspension (Ragheb Esfahani, Hossein Ben Mohammad, 1408, 32)}

Public Prosecution in the implementation of legality pursuit principle, obliged to prosecute all crimes is to somehow be aware of their occurrence (Ravandi, Ghotbodin saeeid, 1405, 62).

Today, from the perspective of criminal policy, pursuit all criminals may not be beneficial in terms of prosecutor, especially in petty crimes that involved density of criminal cases. So another rule as a "pursuit requirement" is allocated in Special place among criminal policy tools. However, Prosecution decided about not to pursuit does not mean that $\mathrm{He}$ intends to not pursuit the person or persons who are involved in the crime, But also the prosecutor is authorized Prior to the expiration of the time that The legislator considered for the prescription of prosecution have intend to pursuit The suspension.

Needless to say, that the decision to suspend pursuit is in the before the trial stage under the authority of the court, While sentencing delayed is in the hearing stage and under the authority of the ruling judge. 
Literally means of wrestling suspension, suspension and hang out, the hanging thing to something and pending (Dehkhoda, Ali Akbar, Dehkhoda dictionary, following the suspension).

Suspension in Latin with the term «probation» is used with the following meanings ${ }^{1}$ :

Acourt-inposed criminal sentence that, subject to stuteb conditions, release a convicted person in to the community inspead of sending the criminal to juilor prison

According to the binding of the sentence court, According to the announced conditions, the convicted or guilty person, instead of being sent to prison is released in the community.

In the French language the term "suspension" is used to mean the following':

Action the suspender quelquen or quelque chose

The act of suspending someone or something

So suspended carrying out the punishment is the Stopping punish someone who Was sentenced to Mandatory or Deterrent penalties if for some time after that Not commit another crime And follow the orders of the court in this period His Condemnation considered overturned.

\subsection{The Idiomatic and Lexical Meaning of Pursuit}

In Latin, the word "Prosecution" is used to mean the following:

The pursuit of legal proceeding, particularly criminal proceeding, attorney general

Someone who follow criminal process (Justice) Special legal process (Justice).

In France, the term "porsuite" is used to mean the following:

Qulqueun pousuite les coupables ou les nalsaitaur.

Someone who pursue and prosecute the offenders.

In order to clarify the concept of suspension of pursuit, initially concept of criminal prosecution expressed. Criminal prosecution means the decision to prosecute the crime and is part of the criminal process. The criminal process begins with the discovery of crime with prosecution and preliminary investigation continues. In the crime discovery stage Necessary measures in order preserve crime and to prevent the accused from escaping carried out. After the discovery phase the crime continuation phase begins. At this stage in relation to sufficiency of charge evidence making a decision. After authentication of evidence sufficiency prosecution begins and Preliminary inquiry begins. Between decision to prosecute and decide to preliminary investigation, there is no time interval. The decision to prosecute ensure decided to research. After notice of crime occurrence the decision to prosecute crime are taken and Preliminary inquiry begins. In case of issuance of culpability case is sent to court. Usually Police discovered the crime, the prosecutor performs the continuation phase and the investigator is usually responsible of preliminary inquiry. The term "criminal prosecution" can be divided from various perspectives. This term from on perspective divided to the narrow and broad. Criminal prosecution in the narrow concept means a decision to prosecute the crime. In a broad concept has a comprehensive range. And are include Necessary measures in order prepare the file to send the court, Measures to defend the indictment in justice step, Actions related to the execution stage (Zeraat,Abaas and Mohajeri Ali, 1382,P48).

The decision to prosecute, prosecutors after reviewing the file facts And examine issues in it including the case of alleged character that has been developed based on the findings of criminology, conclusion, And it makes the chase suspended, And with this action, Interweaved both the personal and social interests and inject interest antidote to the social body, to realize individual and social preventing by this action.

The prosecution suspension is the example of the chase position. Position of having Principle is Ruling On the prosecution and transferred the disposal of the chase to the for prosecution. This principle is considered the antithesis of prosecution obligatory Principle. According to this principle, responsible for prosecution does not have the right to leave prosecution and the right to apply superior alternative to the accused. Based on this principle, responsible for prosecution has the responsibility of pursuing does not have right to apply alternative to the accused. Based on this principle, prosecution state have task of pursuing and preparing the file to send to the court. In this Principle law presumption is that, prosecution every crime is public good ${ }^{3}$.

\footnotetext{
${ }^{1}$ Oxford advanvanced learnees dictionary (7 th editon) Oxford University Press 2002

${ }^{2}$ Larousse( www.larousse.fr/dictionaries/frencais(

${ }^{3}$ Kerley, Gordon, Drug law and enforcement in Australia and the Nether lands, the Australia na-tional university, November 8, 2002, law. Anu.Edu. De/ staffuploads/ 8-kerley 8.doc. p23
} 


\section{Chapter Two}

Basically, Postpones of Sentencing is in three forms:

1) Simple postponement

2) Trial or caring postponed

3) Postponed along with command

In Iran's rights under Article 22 of the new Islamic Penal Code, Postponed is divided into two categories: simple and caring.

\subsection{Simple Postponement}

Simple postponement means that after authentication of defendant's culpability by the court, delayed his punishment and released offenders unconditionally without declare any Punishment. Basically, this decision Be issued in petty crimes and criminals who are less danger and The public powers not seen them as prosecution requires.

Simple postponement not only don't imposing condition like supervised postponement to the offenders, but also criminal record also not be considered. In this decision court in case of Qualifying Article 40 Attempted to issue the suspension punishes, yet the perpetrators must be committed in writing that in the time that court determines shall not be committing Crimes under Article 22 of this Law. Also, from his/her behavior predicted that in the future he/she will not commit a crime (Paragraph a of Article 2 of the Penal Code approved in 1392).

\subsection{Probation}

Issuance Probation is as simple postponement. With the difference that in addition to existence of Conditions for issuing a simple suspension Perpetrator pledged that follow Orders and measures prescribed by the court in the period of suspension or implement on time (Paragraph B of Article 41).

In this type of suspension In addition Perpetrator pledged that Do not commit a crime in article 44, have to do Policies and practices that court to appoint him. These measures set out in Article 21 and 29 new Islamic Penal Code has been proposed is in the two forms. A number of them are measures that must be followed during the period of Postponed. Such measures are mandatory aspects and Sentencing caring without mentioned tightens will not be done. (Sabzevari Nezhad, Hasan, 1391, p49-81). Postponed issuance is authorized in crimes that have been set based on law. But lawmakers in the chapter on punishment Suspension enumerated crimes and convince the court that in crime does not attempted to suspension or postponement. According to Article 47 of Islamic Penal Code Stipulates that: Sentencing and punishment in the following crimes and starting them is not able to be postponed or suspended.

A: Crimes against internal and external security of the country Sabotage in water, electricity, gas, oil and telecommunications system.

B: Organized crime, armed robbery- Robbery with assault, kidnapping and acid attack

C: Show of force and interfere with knife Or any other weapon, Crimes against public morals- formation or manage centers of corruption and prostitution.

D: major trafficking of drug, Alcohol, weapons and ammunition human trafficking.

E: Suspended instead of death, Complicity in murder, Waging war against God and corruption on earth.

F: Economic crimes with the issue of crime over a hundred million Rials.

G: Crimes sentenced from Grade 1 to Grade 5.

Crimes entered in article 47 Islamic Penal Code and start this crime is non-derogable.

1- Regarding to the Paragraph 1 of article 228 of the Islamic Penal Law, Crimes involving authoritative legal sanctions Inclusion of provisions of Article 24 of the Islamic Penal Law are outside about the sentencing postponed.

In this article The purpose of the organized crime is Illegal activities and coordination of A coherent group of persons that with Conspiracy of each other committing continued crime to achieve material and power gains. And use any Tools for achieve the goal.

There is not a clear definition In the case of economic crimes in criminal law and other low. In general it can be said that economic crimes are crimes done against the economy of country and disrupt in the country's economic system. 
Postponed sentencing institutions goals:

\subsubsection{Institutional in Line with Principle of Individualization of Punishments}

With the emergence of new social defense, once again special attention emerged in relation to the criminal person. Discuss of necessity of filing criminal character Caused to Individualization of Punishment matured more than what was raised in fulfillment school. Principle of Individualization of punishment are looking to compliance the punishment with offender character, So that in the light of this, achieve crime modification And thus reduce the phenomenon of criminal. Sentencing Postponed institution is one of the predicted methods in Islamic Penal Code Approved in 1392 that are aimed تفريد punishment at proceedings stage. In this way court considering the personal and social situation and also the circumstances of the commits a crime Has the authority That In determining the punishment for the offender does not accelerate by applying this institution. Also the use of such a body, In addition to reducing the economic costs is also prevents Imposing Political cost to the government, because in the relations between states Human rights are standards and linear stick to judge their repertoire. So whatever a country's criminal law and procedure, have been fast and furious that government will have drop points on his record (Najafi Abrand Abadi, Ali Hossein 1382 p62).

\subsubsection{Institutional to De-Judiciary}

Given that in many offenses cannot be made to decriminalize, Governments prefer that using de-judicialization Prevent perpetrators from engaging in the criminal justice process or by entering in this process, Prevent it from continuing or lead it to the right path. New methods of diversion are looking for that Not only prevent from entering the criminal justice system, but also by provide social solutions Fixes crime disruption or repair social relations. (Rayjian Asli, Mehrdad 81, p89).

The Postponed sentencing institution, Leading to the diversion Because the court after taking the culpability of the wrongdoer Immediately does not apply penalty in relation to him But also for a while his/her sentences are suspended. In addition, In addition, if the criminal justice system since the discovery of crime until the performance penalty And even care After departure is involved, Load the criminal justice system will be reduced Using such funding agencies.

\subsubsection{Principles of Islamic Punishment}

In each country, some behaviors are considered as a crime that the first and most basic reaction against this criminal behavior is performance punishment. Punishment has Features and specifications that can finally restore discipline to society, although this restoration of order may not be able to meet Losses from crime generally, but can provide support background from the community and the victim to a large extent.

Should be noted that in the past, if someone was convicted of a crime all relatives and family of that person were subject to the revenge of victim's family. But after years of principles governing sanctions that Compliance with these principles can provide fair trial and Lawful implementation. So when basis of punishment in Islam are Mercy to people, meet their interests, evil Excretion from them and equality, Basic principles should be governed to reach the desired goal(Ardebili, Mohammad Ali, 1385, p 130)

Some of them are listed below:

\subsubsection{Proportionality between Crime and Punishment}

In fact this principle is result of Lord Justice. In addition, punishment based on Necessity has been Legislated Considered contrary to the principle. Therefore, in applying the extent necessary is sufficient, and proportion between punishment and crime should be considered.

In the Continue this principle will be explain.

The second principle: As we have stated in punishment interests of the society have been considered. So, when a crime is conducted, the punishment should be such that urbanize the offender and dissuade others from committing crime. For example, because of the importance that Islam has given to person and his character, unjustly kill a man are regarded kill all humans.

The third principle: Because the purpose of punishment is for interests of the society it can be as strong and weak, sufficiently. And Be intensity, when interests of the society is in severe punishment, and when interests of the society is in Slight punishment, Be mild. This has been supplied by embedding punishment in Islamic penal law.

The fourth principle: Correction criminal is purpose of punishment in Islam. But Correction as many popular jurisprudents have said, never means revenge, unlike what is stated in some theories. 


\section{Conclusion}

One of the major institutions that has written and adopted in the law is "procrastination sentencing". In fact we can say that the basic philosophy verdict procrastination principle is based on Labeling Theory that in fact guilty Label not be attach to those accused crimes. Of course, according to the law, the court does not have this authority for procrastination sentencing for all offenses, But in the field of prison crime that many crimes are in this area anyway, and crimes related to the execution demand the court can postpone sentencing after guilty Authentication.

Given that the crime committed under the specific circumstances of the people may take place Such as, for example, offender may be young, crime has been done with honorable motivation, Or offender is young and require leniency and opportunity and the perfect backdrop to once again return to society, Therefore, the procrastination is appropriate from this perspective And can cause the individual turn back to the society.

So we can say that procrastination sentencing is legal term that Legislators, commonly used. That's mean under particular circumstances It is possible sentencing delayed despite existence the criminal element.

Procrastination sentencing institution is built to support non-dangerous offenders, and is considered, with justifications such as Avoid labeling the perpetrators of crime as an exception to the principle stated. Procrastination sentencing institution original (Stipulated in Article 40 the Islamic Penal Code) has been adapted from the French Penal Code.

Thus, one of the innovations the Islamic Penal Code in 1392 is forecasting procrastination sentencing. Which during article 40 to 45 examined, it should be noted that sentencing procrastination that in Suspended crime with grade 6 to 8 is applicable is Due to Criminology data And sometimes is towards advanced criminal law. The legislator has predicted that Sometimes the lack of applying punishment And just sentencing s sufficient to punish Guilty and here Legislators have gone a step further and Before judge sentencing According to the principle of individualizing the punishment that focuses on Criminal character and other different aspects, by condition Authentication delay sentencing for six months to two years.

\section{References}

Abazari Fomeshi, M. (1387). Operation Mode drafting of defense bill In the legal claims. Tehran, Publication of Khorsandi.

Al Taha, S. H. (1386). The appropriateness of version penalties with Crime and criminals character in the view of Islam. Thesis MA in Criminal Law and Criminology. Islamic Azad University, Qom.

Ardebili, M. A. (1382a). General criminal law (Vol. 1, 4th ed.).Tehran, Mizan.

Ardebili, M. A. (1382b). Criminal liability arising from the act Non in Iran criminal law. Journal of Legal Studies, 16-17.

Ashuri, M. (1368). Code of Criminal Procedure (Vol. 1, 8th ed.). Tehran. Samt.

Bakhshy Zadeh, A. (1391). Developments in the Islamic Penal Code (1st ed.). Ghoghnus Publishment, Tehran.

Bakhshy Zadeh, A. (1392). Mahshi the Islamic Penal Code (1st ed.). Javid No Publishment, Tehran.

Blix, B. (1389). Culture of legal theory. Translation: Muhammad Rasekh, Tehran: Nei Publishing.

Bvhlandr, M. (1389). Germany Penal Code. translated: Asli Abbasi, Tehran: Majd.

Delaware, A. (1383). Scientific theory and research in the humanities and social sciences (3rd ed.). Thran: Publications growth.

Ebn Mansour. (1408). Lesan AL Arab. Tome 3. Beiroot: Altras revival of Arabi, first Edition.

Ekhvat, M. A. (1377). Interpretation of the Islamic Penal Code: The principle of legality of crime and punishment/ second part. Proceedings Journal, (11), 38-44.

Jafari, M. (1392). "Sociology of criminal law", critical approach to Criminal rights. Tehran. Mizan.

Jamshidi, A. (1382). policy discourse criminal justice bill law. Children and Youth Court, Journal of Law and judiciary, (28).

Pynatl, J. (1365). alternative punishments and criminology. translation: Ali Hussain Najafi Abrand Abadi. The right Journal, Legal and Judicial Studies, (6).

Stephanie, G., Lvasvr, G., \& Bullock, B. (1377). General criminal law, Translation: Hassan Dadban. Volum2. Tehran: Allameh Tabatabaei university. 
Tavajohi, A. (1391). General criminal law pleadings lessons. MA, Tehran University.

The prosecutor, P. (1389). Criminal Psychology (7th ed.). Tehran. Samt.

Zadeh, H., Jafar, M., \& Zeinali, H. (1384). Introduction to some restrictions, practical criminalization. letters Mofid, Mofid University Journal, XI(49).

\section{Copyrights}

Copyright for this article is retained by the author(s), with first publication rights granted to the journal.

This is an open-access article distributed under the terms and conditions of the Creative Commons Attribution license (http://creativecommons.org/licenses/by/4.0/). 